\title{
Doctoral Dissertations \\ on Russia, the Soviet Union, and Eastern \\ Europe Accepted by American, \\ Canadian, and British Universities, 1976-1977
}

\author{
BY JESSE J. DOSSICK
}

The observation made last year, that a plateau may have been reached in the annual output of doctoral research on Russia and the Soviet Union, applies also to this year's listing. While the total number of dissertations compares favorably with past years, there does not seem to be the kind of steady growth that was characteristic of the decade preceding 1974, the peak year in output to date. Next year's statistics should be enlightening in this respect. Of the two hundred and eighty-eight titles in the current list, two are from 1973, seventeen from 1974, twenty-two from 1975, one hundred and seventy from 1976, and seventy-seven from 1977. While this list contains seven more titles than last year's, the task of the compiler in preparing the list is becoming increasingly difficult because a growing number of universities, out of a desire to economize on typing, printing costs, and secretarial work, have discontinued the practice of compiling master lists. Because degrees are also granted by most universities past the usual spring commencement, with some as late as December, and because of the very late appearance of American Doctoral Dissertations (by as much as two years) and a publication deadline, complete coverage for the 1977 calendar year is not possible at this time. Eighty universities are represented (seventy-four in the United States, five in Canada, and one in Australia).

The listing for Eastern Europe contains ninety-five dissertations from forty-five American and four Canadian universities. This number of dissertations represents a sharp drop of twenty-six from last year's number. The separate British list is also much smaller and contains twenty-four titles representing the output of eight universities. Regrettably the 1977 list from Oxford and other British universities was not received at the time of completing this present list.

For a list of dissertations accepted through 1959 see the author's Doctoral Research on Russia and the Soviet Union (New York, 1960). An accompanying volume 2, Doctoral Research on Russia and the Soviet Union, 1960-1975 (New York: Garland Publishing Inc., 1976) is also now available. Volume 2 contains not only the more than three thousand titles which have appeared in the listings published annually in the December issue of Slavic Review since 1964 (the 1964 listing also included dissertations accepted in 1960-63), but also items not previously listed in volume 1 . In addition, volume 2 offers some critical and statistical analysis, over thirty major classifications, numerous sub- and sub-subclassifications, cross references, an index of Russian and Soviet names, and an index of authors. 


\section{AMERICAN AND CANADIAN DISSERTATIONS}

\section{Russia and the Soviet Union}

\section{AGRICULTURE}

Gray, Kenneth Royal. "The Efficient Location and Specialization of Soviet Agricultural Procurement," Wisconsin, 1976.

Messmer, William Bruce. "Soviet Agriculture and the Third World: A Case Study of Cuba," Ohio State, 1976.

Murray, James Patrick. "The All-Union Farm Machinery Association 'Soiuzsel'khoztekhnika': A History of Its Role in Soviet Agriculture, 1961-1971," New York, 1976.

\section{ANTHROPOLOGY}

Rathburn, Robert Richard. "Process of Russian-Tlingit Acculturation in Southeastern Alaska," Wisconsin, 1976.

\section{ART}

Douglas, Charlotte Cummings. "Swans of Other Worlds: Kazimir Malevich and the Origins of Suprematism, 1908-1915," Texas, 1975.

Edgington, K. Ann. "Abstraction as a Concept in the Criticism of Gertrude Stein and Wassily Kandinsky," American, 1976.

Kennedy, Janet Elspeth. "The Mir iskusstva Group and Russian Art 1898-1912," Columbia, 1976.

Levin, Sandra Gail. "Wassily Kandinsky and the American Avant-Garde, 19121950," Rutgers, 1976.

\section{DRAMA AND THEATER}

Farber, Vreneli Regula. "The Repertoire of the Sovremennik Theater as Representative of a Trend in Soviet Drama 19561970," Indiana, 1976.

Hellweg, John D. "The Dimensions of Language, Character, Time and Space in Chekhov's Major Plays," California, Berkeley, 1975.

Law, Alma Hanson. "A Reconstruction of Meyerhold's Production, Woe to Wit: The Relationship Between Literary Text and Theatrical Presentation," Columbia, 1977.

Mayer, Charles Steven. "The Theatrical Designs of Leon Bakst," Columbia, 1977.

Roberts, Jerry Wayne. "The Theatre Theory and Practice of Richard Boleslavsky," Kent State, 1977.

Taschian, Norair Noric. "Nikolai Evreinov, The Theorist of the Russian Theater," California, Berkeley, 1974.

\section{ECONOMICS}

Boncher, William Hector. "Innovation and Technical Adaptation in the Russian Econ- omy: The Growth in Unit Power of the Russian Mainline Freight Locomotive," Indiana, 1976.

Low, Loh Lee. "A Study of Four Major Groundfish Fisheries of the Bering Sea," Washington, Seattle, 1974.

Rabin, Sheldon T. "Soviet-Owned Banks in Europe: Their Development and Contribution to Trade with the West," Johns Hopkins, 1977.

Turpin, William Nelson. "Soviet Foreign Trade: Purpose and Performance," George Washington, 1976.

\section{EDUCATION}

Chaplin, Miriam Thomas. "Implications in the Theories of Lev Vygotsky, Jean Piaget, George Kelly and Erik Erikson for the Assessment of Instruction in College Reading," Rutgers, 1976.

Eklof, Arthur Benoit. "Spreading the Word: Primary Education and the Zemstvo in Moscow Province, 1864-1910," Princeton, 1977.

Galskoy, Constantin. "The Ministry of Education under Nicholas I: 1826-1836," Stanford, 1977.

Kassow, Samuel David. "The Russian University in Crisis, 1899-1911," Princeton, 1976.

Kyshakevych, Tatiana. "University Education in Ukraine," Pittsburgh, 1976.

Markus, Roberta Lander. "Teaching about the Westerner in the Soviet Union: Images of the American, Englishman and Frenchman as Portrayed in Foreign Language Textbooks Utilized in Regular and Special Language Schools in the U.S.S.R.," Toronto, 1976.

Popovecz, Andrew, Jr. "Higher Education in the Soviet Union: A Descriptive Study," Wayne State, 1976.

Szumaski, Annette Marlene. "The Impact of Concrete Social Research on the Soviet Policymaking Process: A Case Study in Contemporary Educational Reforms," George Washington, 1976.

\section{GEOGRAPHY}

Clem, Ralph Scott. "The Changing Geography of Soviet Nationalities and Its Socioeconomic Correlates: 1926-1970," Columbia, 1976.

Huning, James Robert. "A Visualization of Seasonal and Annual Precipitation Variability in the Soviet Union," California, Riverside, 1976. 


\section{HISTORY}

\section{A.D. 896 to 1700}

Kuuskvere, Mart S. "The Baltic German Nobility of Estonia and Livonia, A Political Study: From Crisis to Stability 16751725," New York, 1976.

Ostrowski, Donald Gary. "A 'Fontological' Investigation of the Muscovite Church Council of 1503," Pennsylvania State, 1977.

Pernal, Andrew B. "The Polish Commonwealth and Ukraine: Diplomatic Relations 1648-1659," Ottawa, 1977.

Sysyn, Frank. "Adam Kysil, Statesman of Poland-Lithuania: A Study of the Commonwealth's Rule of the Ukraine from 1600 to 1653 ," Harvard, 1976.

Zlotnik, Marc David. "Immunity Charters and the Centralization of the Muscovite State," Chicago, 1976.

\section{Eighteenth Century}

Dailey, Diane Barbara. "The Politics of the Roman Catholic Episcopate in the PolishLithuanian Commonwealth, 1764-1772," Washington, Seattle, 1977.

James, William Alexander. "Paul I and the Jesuits in Russia," Washington, Seattle, 1977.

Leonard, Carol Scott. "A Study of the Reign of Peter III of Russia," Indiana, 1976.

Warner, Richard Hyde. "The Political Opposition to Tsar Paul I," New York, 1977.

\section{Nineteenth Century}

Ackelsberg, Martha Ann. "The Possibility of Anarchism: The Theory and Practice on Non-Authoritarian Organization," Princeton, 1976. [Bakunin and Kropotkin]

Bergman, Jay A. "Vera Zasulich and the Politics of Revolutionary Unity," Yale, 1977.

Bournoutian, George A. "Eastern Armenia on the Eve of the Russian Conquest: The Khanate of Erevan under the Governorship of Hoseyn Qoli Khan Qajar, 18071827," California, Los Angeles, 1976.

Brown, John Halit. "A Provincial Landowner: A. T. Bolotov (1738-1833)," Princeton, 1977.

Carver, John Scott. "Vasilii Mikhailovich Severgin, 1765-1826: Russian Scientist, Technologist and Editor," Temple, 1977.

Cocks, Pamela Pfaff. "'Russkoe Slovo,' 1859-1866: Spokesman for Russian Nihilism and Realism," Boston College, 1974.

Coffey, Steven James. "A. I. Koshelëv and the Emancipation of the Russian Serfs, 1847-1862," Wisconsin, 1976.

Fry, Gary Dean. "The Doukhobors, 18011855: The Origins of a Successful Dissident Sect," American, 1976.

Goldberg, Rochelle, "The Russian Women's Movement: 1859-1917," Rochester, 1976.
Hewitt, Gerald W., Jr. "Revolution, Tradition and Order. The .Nineteenth Century Anarchist Experience," SUNY, Binghamton, 1977.

Ivancevich, Anthony Mario. "The Ukrainian National Movement and Russification," Northwestern, 1976.

Kneip, James Robert. “A. S. Griboedov: His Life and Work as a Russian Diplomat, 1817-1829," Ohio State, 1976.

Macey, David Anthony James. "The Russian Bureaucracy and the 'Peasant Problem': The Pre-History of the Stolypin Reforms, 1861-1907," Columbia, 1976.

McDaniel, James Frank. "Political Assassination and Mass Execution: Terrorism in Revolutionary Russia, 1878-1938," Michigan, 1976.

Orlovsky, Daniel Ted. "Ministerial Power and Russian Autocracy: The Ministry of Internal Affairs 1802-1881," Harvard, 1976.

Pelech, Orest. "Toward a Historical Sociology of the Ukrainian Ideologues in the Russian Empire of the 1830's and 1840's," Princeton, 1976.

Pogorelskin, Alexis Esther. "Scholar and Journalist: The Career of M. M. Stasiuelevich, 1850-1882," Yale, 1976.

Roosevelt, Priscilla Reynolds. "T. N. Granovskii: Universal Historian and Russian Intelligent," Columbia, 1977.

Rose, Jerman Walter. "The Russian Peasant Emancipation and the Problem of Rural Administration; The Institution of the Mirovoi Posrednik," Kansas, 1976.

Sorenson, Thomas C. "The Thought and Policies of Konstantin P. Pobedonostsev," Washington, Seattle, 1977.

Stack, Shannon Caroline. "Herat: A Political and Social Study," California, Los Angeles, 1975.

Thackeray, Frank William. "Alexander I and the Polish Congress Kingdom: A Study in Russo-Polish Political Relations, 1815-1825," Temple, 1977.

Turgay, A. Uner. "International Politics, Economic Development and Social Change in Trabzon in the Nineteenth Century," Wisconsin, 1976.

Weeks, Richard George, Jr. "Peter Andreevich Shuvalov: Russian Statesman," Minnesota, 1977.

Wetzel, David. "The Diplomacy of the Crimean War," Chicago, 1976.

Zatlokal, Barbara Margaret. "The Foreign Image of Mickiewicz in Nineteenth and Twentieth Century Criticism and Public Opinion in Europe and America," Indiana, 1976.

\section{0 to 1918}

Brym, Robert Joseph. "Strangers and Rebels: The Russian-Jewish Intelligentsia in Marxist Social Movements at the Turn 
of the Twentieth Century," Toronto, 1976.

Carley, Michael Jabara. "The French Intervention in the Russian Civil War, November 1917-April 1919," Queen's (Canada), 1976.

Drumm, Robert Elmer. "The Bolshevik Party and the Organization and Emancipation of Working Women, 1914 to 1921 ; or a History of the Petrograd Experiment," Columbia, 1977.

Eiter, Richard H. "The Organizational Growth of the Socialist Revolutionary Party, 1901-1907," Pittsburgh, 1977.

Engelstein, Laura. "Moscow in the 1905 Revolution: A Study in Class Conflict and Political Organization," Stanford, 1976.

Fontenot, Michael James. "Alexander F. Kerensky: The Political Career of a Russian Nationalist," Louisiana State, 1976.

Holt, Charles E., Jr. "English Liberals and Russia, 1895-1907," Kentucky, 1976.

Hongiwachs, Lea Halpern. "The Edwardian Discovery of Russia 1900-1917," Columbia, 1977.

Jones, M. Ellen. "The Uses and Abuses of Article 87: A Study in the Development of Russian Constitutionalism, 1906-1917," Syracuse, 1975.

Koenker, Diane Gail Powerance. "Moscow Workers in 1917," Michigan, 1976.

Lane, Ann Marie. "Nietzsche in Russian Thought, 1890-1917," Wisconsin, 1976.

Lerner, Lawrence Wilfred. "The Progressists in the Russian State Duma, 19071915," Washington, Seattle, 1976.

Olavi, Arens. "Revolutionary Developments in Estonia in 1917-18 and Their Ideological and Political Background," Columbia, 1976.

Radovich, Frances Ann. "Aftermath to Regicide: British Policy and the Siberian Conspiracy Question, 1903-1906," California, Santa Barbara, 1974.

Richardson, William Harrison. "Zolotoe Runo and Russian Modernism: 1905-1910," California, Berkeley, 1976.

Rorlich, Azade-Ayse. "Transition into the Twentieth Century: Reform and Secularization Among the Volga Tatars," Wisconsin, 1976.

Weissman, Neil Bruce. "State, Estate and Society in Tsarist Russia: The Question of Local Government, 1900-1908," Princeton, 1977.

\section{SOVIET HISTORY, POLITICS, LEGAL INSTITUTIONS, NATIONALITY POLICY, AND POLITICAL THOUGHT}

Bahry, Donna L. "An Analysis of the Soviet Budgetary Process," Illinois, 1977.

Bough, Bennie Edward. "The Problem of
Djugashvili: The Stalin Issue in Soviet Politics," George Washington, 1977.

Bunce, Valerie Jane. "Elite Succession and Policy Change in Communist and Democratic Systems," Michigan, 1976.

Cervantes, Frederick Arnold. "An Interpretation of J. V. Stalin's Political Thought," Washington, Seattle, 1976.

Corcoran, Edward Ambrose. "Dissension in the Soviet Union: The Group Basis and Dynamics of Internal Opposition," Columbia, 1977.

Echols, John Minor III. "Politics, Policy and Equality Under Communism and Democracy," Michigan, 1976.

Eminov, Mumunali Mumun. "The Development of Soviet Nationality Policy and Current Perspectives on Ethnicity," Indiana, 1976.

Fitzgerald, John Hoyt. "The Interaction of Demographic Trends in Siberia and Developmental Policy as a Problem for the Soviet Government, 1959-1975," Notre Dame, 1977.

Fugate, Bryan Irven, Jr. "Thunder on the Dnepr: The End of the Blitzkrieg Era, Summer, 1941," Texas, 1976.

Hayes, Nicholas Patrick. "The Intelligentsia-in-Exile: Sovremennye zapiski and the History of Russian Emigré Thought, 1920-1940," Chicago, 1976.

Jones, William Milton. "Maintaining Public Order in the Soviet Union: The Militia and the MVD in the Post-Khrushchev Era," Duke, 1976.

Knarr, John Richard. "Population Politics and the Soviet Polity," California, Los Angeles, 1976

Minagawa, Shugo. "Presidia and Standing Commissions of the Federal and Republican Supreme Soviets in the USSR, 19581972," Australian National, 1975.

Muniandy, Thambirajah. "The Collapse of the Anti-Bolshevik Movement in South Russia, 1917-1920," Washington, Seattle, 1975.

Parrott, Bruce Bassett. "Technology and the Soviet Polity: The Problem of Industrial Innovation, 1928 to 1973 ," Columbia, 1976. Smith, Gordon Budd. "The Monitoring Agency: Procuratorial Supervision of Administration in the Soviet Union," Indiana, 1976.

\section{SOVIET DIPLOMACY, POLICY, AND FOREIGN RELATIONS}

Gidwitz, Betsy Rose. "The Political and Economic Implications of the International Routes of Aeroflot," Washington, Seattle, 1976.

Platt, Alan R. "The Olympic Games and Their Political Aspects: 1952-1972," Kent. State, 1976. 
The United States and the USSR

Arum, Stephen Marshall. "Early Stages of Foreign Language and Area Studies in the U.S.: 1915-1941," Columbia, 1975.

Barnes, Harley Hassinger, Jr. "The Nuclear Non-Proliferation Treaty: Participants, Interests, and Processes in American Foreign Policy Formulation," Rutgers, 1976.

Beckman, Peter Roane. "The Influence of the American Military Establishment on American Foreign Policy, 1946-1970," Wisconsin, 1974.

Biggs, Tyler Sanford. "Political Economy of East-West Trade: The Case of the 19721973 U.S.-Russian Wheat Deal," California, Berkeley, 1976.

Blumoff, Theodore Yale. "Popular Fiction and the Creation of a Cold War Consensus, 1943-1952," Saint Louis, 1976.

Calhoun, John Humphrey. "The Frustration of Power: United States Military Policy, 1945-60," York, 1976.

Cheng, Guang-Meei Doris Chang. "A Study of the Impact of U.S. Grain Exports on the Exchange Rate and the Domestic Price Level," Notre Dame, 1976.

Claussen, Martin Paul. "American-Soviet Relations and the Russian Famine, 19211923," George Washington, 1976.

Collins, Catherine Anne. "Kissinger's Press Conferences: 1972-1974: A Rhetorical Assessment of Form, Substance, and Strategy," Minnesota, 1977.

Daly, Judith Ayres. "The Superpowers: Perceptual, Behavioral and Capability Dynamics, 1950-1965," Georgetown, 1976.

DeVries, Robert Lee. "The Formulations of American Policy on the Control Provisions of the Non-Proliferation Treaty," Michigan, 1974.

Domer, Thomas Michael. "Sport in Cold War America, 1953-1963: The Diplomatic and Political Use of Sport in the Eisenhower and Kennedy Administrations," Marquette, 1976.

Elkin, Jerrold Frederick. "The North Russia Aid Program, 1942: Decision Making in a General Warfare Context," Pennsylvania, 1976.

Fox, Cindy Judy. "The Exchange of Easel and Plastic Arts: Soviet-American Cultural Relations, 1945-1976," Tufts, Fletcher School of Law and Diplomacy, 1977.

George, Roger Zane. "Contending Views of National Security, 1969-1973," Tufts, Fletcher School of Law and Diplomacy, 1977.

Gormly, James L. "In Search of a Postwar Settlement: The London and Moscow Foreign Ministers' Conferences of 1945, and the Origins of the Cold War," Connecticut, 1977.

Gross, Bertram W. "An Analysis of the Debate in the United States Senate on the
Safeguard Antiballistic Missile System," Temple, 1975.

Harbutt, Fraser Jefcoate. "The Fulton Speech and the Iran Crisis of 1946: A Turning Point in American Foreign Policy," California, Berkeley, 1976.

Harris, Ruth Ruhr Roy. "The Shifting Winds: American-Soviet Rapprochement from the Fall of France to the Attack on Pearl Harbor, June 1940-December 1941," George Washington, 1975.

Hinds, Lynn Boyd. "The Rhetoric of AntiCommunism: A Criticism of Selected Speeches by Leading Anti-Communist Speakers," Pittsburgh, 1977.

Hindson, Theodore Thomas. "The Soviet Union in American Eyes: An Examination of Some American Opinion Toward the USSR in the Period Between the GermanSoviet Pact and the Dissolution of the Comintern," Notre Dame, 1977.

Hull, Elizabeth Anne. "Sherman Minton and the Cold War Court," New School, 1977.

Ilkka, Richard Jacob. "The Rhetorical Vision of the American Communist Movement; Origin and Debut, 1918-1920," Minnesota, 1974.

Karl, John Francis. "Compromise or Confrontation: James F. Byrnes and United States Policy Toward the Soviet Union, 1945-1946," Toronto, 1976.

Kratochwill, Fredrick Viktor. "International Order and Foreign Policy," Princeton, 1976.

Kuniholm, Bruce Robellet. "The United States, the Northern Tier, and the Origins of the Cold War: Great Power Conflict and Diplomacy in Iran, Turkey, and Greece," Duke, 1976.

Leigh, Michael. "Public Opinion, American Foreign Policy and the Origins of the Cold War," Massachusetts Institute of Technology, 1974.

Martel, Leon Charles, Jr. "Lend-Lease, Loans and the Coming of the Cold War: A Study of the Implementation of Foreign Policy," Columbia, 1977.

McGrath, Hugh Peter. "Cold War Liberalism and the Chilling Effect on Freedom of Expression," Chicago, 1974.

Meyer, Albert Joseph. "Deradicalization: The Case of Former Trotskyists," SUNY, Albany, 1977.

Moskovits, Shlomo. "The United States Recognition of Israel in the Context of the Cold War, 1945-1948," Kent State, 1976.

Newman, Parley Wright, Jr. "The Origins of the North Atlantic Treaty: A Study in Organization and Politics," Columbia, 1977.

Sanders, Jane Agnes. "Academic Freedom at the University of Washington During the Cold War Years: 1946-1964," Washington, Seattle, 1976.

Shoup, Laurence Henry. "Shaping the Na- 
tional Interest: The Council on Foreign Relations, the Department of State, and the Origins of the Postwar World, 19391943," Northwestern, 1974.

Skowronek, Paul George. "U.S.-Soviet Military Liaison in Germany Since 1947," Colorado, 1976.

Steiner, James Edward. "Economic Methods for Military Threat Assessment," Georgetown, 1977.

Tillapaugh, James C. "From War to Cold War. United States Policies Toward Latin America, 1943-1948," Northwestern, 1973.

Urban, Michael Edward. "Ideology and Administration in the United States and the Soviet Union," Kansas, 1976.

Van Wormer, James William. "Sputnik and American Education," Michigan State, 1976.

Weil, Martin. “The Struggle for Control of American Foreign Policy: The State Department, 1933-1946," Harvard, 1975.

Wix, William Mervin. "The Army's Plans for Its Postwar Role, 1943-1945," Columbia, 1976.

Zatuchni, Stephen Barry. "On Deterrence: The Role of Weapons Systems in the Formation of United States Defense Policy, 1968-1975," Temple, 1976.

\section{Europe and the USSR}

Leich, John Foster. "Communist Parties in the European Parliament: The Quest for Legitimacy," Massachusetts, 1976.

Potter, William Clark. "Continuity and Change in the Foreign Relations of the Warsaw Pact States, 1948-1973: A Study of National Adaptation to Internal and External Demands," Michigan, 1976.

Tannahill, Roy Neal. "The Communist Parties of Western Europe; A Comparative Study," Rice, 1976.

Ungar, Amiel Aryeh. "Quiet Diplomacy versus Assertiveness in Western European Communism; the Case of the $\mathrm{PCF}$ and PCI," Columbia, 1977.

\section{Finland and the USSR}

Lydon, Maria L. Kolhonen. "Finnish-Soviet Economic Cooperation with a Case Study of the Saimaa Canal Project," New School, 1977.

\section{France and the USSR}

Fry, Earl Howard. "Executive Policy-Making in Gaullist France: The Case of Franco-Soviet Relations, 1958-1974," California, Los Angeles, 1976.

Lacome, Denis Charles Joseph. "The Red Notables: French Communism and Socialism at the Grassroots," Yale, 1976.

Lockwood, Robert Stephen. "Gaullist Foreign Policy: NATO Withdrawal and Systemic Change," George Washington, 1976.
Santore, John Frank. "The Foreign Policy of the French Communist Party, 1931-1935," Columbia, 1976.

Steinfels, Peter T. "French Left-Wing Intellectuals and Foreign Policy; The Ligue des Droits de l'Homme, 1931-1939," Columbia, 1976.

\section{Germany and the USSR}

Dzirkalis, Andrew Edward. "Party Doctrine and Foreign Policy: The Social Democrats and West German Foreign Policy, 1945-1965," Columbia, 1976.

Kawalewale, Kammalizeni Julius. "Ostpolitik and West German Public Opinion: An Interpretation," Miami University (Ohio), 1976.

Smith, David Brent. "The Opposition to Ostpolitik: Foreign Policy as an Issue in West German Politics, 1969-1972," Harvard, 1976.

\section{Great Britain and the USSR}

Holden, David Richard. "The First New Left in Britain, 1956-1962," Wisconsin, 1976.

\section{Italy and the USSR}

Adamson, Walter L. "The Political Thought of Antonio Gramsci: A Study in the Marxist Conception of Political Education," Brandeis, 1976.

Lange, Peter Michael. "Change and Choice in the Italian Communist Party: Strategy and Organization in the Postwar Period," Massachusetts Institute of Technology, 1975.

\section{Africa and the USSR}

Abate, Yohannis. "Foreign Aid, UN Voting Behavior, and Alliances: The Case of Africa, the U.S., and the USSR," Michigan State, 1976.

\section{The Middle and Near East and the USSR}

Chubin, Shahram. "Iran's Foreign Policy 1958-1972: A Small State's Constraints and Choices," Columbia, 1974.

Darvich-Kodjouri Djamchid. "Image and Perception in International Relations: A Case Study of Relationship Between Iran and the Great Powers, 1919-1953," Miami University (Ohio), 1976.

Dooley, Howard John. "The Suez Crisis, 1956: A Case Study in Contemporary History," Notre Dame, 1976.

Fatemi, Faramarz S. "The USSR in Iran: The Irano-Soviet Dispute and the Pattern of Azerbaijan Revolution 1941-1947," New School, 1976.

Hatzilambrou, Lambros. "Soviet Foreign Policy in the Eastern Mediterranean: A Systematic Approach," Howard, 1976.

Hensel, Howard Milton. "Soviet Policy in 
the Persian Gulf: 1968-1975," Virginia, 1976.

Levin, Nehemia. "The Attitudes of Jewish Administrators of Russian, Polish, and Israeli Descent in Institutions of Higher Education in Israel toward Students of Ashkenazic and Sephardic or Oriental Background," Connecticut, 1977.

Shattan, Joseph Jacob. "Soviet Military Aid and the Politics of Leverage: The SovietEgyptian Case," Tufts, Fletcher School of Law and Diplomacy, 1977.

Tennenboim, Mark (Mordekhai). "SovietEgyptian Relations October 1964-September 1970: Brezhnev and Abdal-Nàsir," New York, 1977.

\section{India and the USSR}

Pandher, Rachhpal Singh. "An Analysis of the Indian Foreign Policy in the PostNehru Period: A Case Study of the Bangla Desh Crisis Management," Howard, 1975.

\section{China and the USSR}

Hefron, Peter Oslin. "Ideology and Chinese Foreign Policy During the Eighth Central Committee, 1956-69," Tufts, Fletcher School of Law and Diplomacy, 1976.

Ou, Hsin-Hung. "Communist China's Foreign Policy Toward the War in Vietnam, 1965-1973," Southern Illinois, 1977.

Reardon-Anderson, James Byron. "The Foreign Policy of Self-Reliance: Chinese Communist Policy Toward the Great Powers, 1944-1946," Columbia, 1976.

Smyser, William Richard. "North Vietnam and the Sino-Soviet Split, 1956-1969," George Washington, 1977.

\section{Japan and the USSR}

Blaher, Michael Kent. "Patterns in Japan's International Negotiating Behavior Before World War II," Columbia, 1973.

Ro, Chun Whang. "The Origins and Interpretation of the 1951 U.S.-Japanese Security Treaty," Southern Illinois, 1977.

\section{Korea and the USSR}

Kiyosaki, Wayne S. "North Korea's Foreign Relations: The Politics of Accommodation (1945-1975)," George Washington, 1976.

Park, Kyoung Suh. "The Republic of Korea's Quest for an Autonomous Foreign Policy (1963-1973): A Critical Analysis," American, 1976.

Yoo, Se Hee. "The Korean Communist Movement and the Peasantry Under Japanese Rule," Columbia, 1974.

\section{LANGUAGE}

Alt, Theresa Frances. "The Language of the Lithuanian Statute of 1529: Orthography, Phonology, Inflections," Columbia, 1977.
Bourke, Michael Kevin. "A Semantic ReExamination of Aspect and Manner of Action in Russian," Brown, 1976.

Brzycki, Dolores. "Teaching Language and Culture Through the Soviet Press," Ohio State, 1976.

Channon, Robert. "Topics in a Relational Grammar of Russian," Harvard, 1977.

Gallant, Charles James III. "Russian Verbal Prefixation and Semantic Features: An Analysis of the Prefix VZ-," California, Los Angeles, 1977.

Hoffman, Janet Lynne. “A Morphological Analysis of the Historical Tales of Semën Ivanovič Saxovskoj," New York, 1977.

Levine, James S. "Towards a Transformational Account of Derived Adjectives in Russian," Iltinois, 1977.

McNaughton, Alan Ross. "Taz Selkup: The Phonology and Morphology of the Verb," Columbia, 1976.

Morgan, Thomas Wallace. "Teaching Russian Pronunciation at the Elementary Level of Language Study," Ohio State, 1976.

Ojamaa, K. "Temporal Aspects of Phonological Quality in Estonian," Connecticut, 1977.

Rakusan, Jaromira. "Derivational Patterns of Russian Nouns with Suffixes of Subjective Evaluation," Ottawa, 1977.

Rasch, Barbara Jean. "A Syntactic Analysis of Word Formation in Russian with Particular Emphasis on .Deverbal Nouns," Washington, Seattle, 1977.

Salimi, Hosseingholi. "A Generative Phonology of 'Azerbaijani," Florida, 1976.

\section{LITERATURE}

Adler, Judith Lowitz. "Spatial Configuration in Late Dostoevsky," Pennsylvania, 1976.

Adrianow, Gennadij Yakovlevič. "The Importance of Lexical and Socio-Cultural Symbolism in A. V. Sukhovo-Kobylin's Trilogy," McGill, 1976.

Arnesen, Hildegard Johanna. "Vozmezdie: The Concept of Retribution in the Poetry of Aleksandr Blok," Washington, Seattle, 1976.

Arthur, Donald Bryon. "Love, Death, and World's End: Themes in Briusov's Prose," Texas, 1976.

Aykut, Altan. "The Poetry of the PreSymbolist K. K. Slučevskij," New York, 1976.

Bakalar, Paul Francis. "A Critique of Leo Tolstoy's What Is Art?," Northwestern, 1976.

Balogun, Fidelis O. "Contemporary Soviet Short Stories: The Last Three Decades (1950s-1970s)," Illinois, 1977.

Baloueff, John J. "Reflection of the Young Intelligentsia in Russian Fiction 19051914," [Russian Text], Vanderbilt, 1976. 
Berczynski, Thomas Stanley. "Benediktov and His Early Poetry: A Different Drum," Indiana, 1976.

Berzups, John Adam. "Ivan A. Bunin and the Soviet Regime," Georgetown, 1976.

Boegeman, Margaret Boyd. "Paradox Gained: Kafka's Reception in English from 1930 to 1949 and His Influence on the Early Fiction of Borges, Beckett and Nabokov," California, Los Angeles, 1977.

Bohart, Eugene. "An Exploration in Novel Form of the Literary Theme of Spiritual Rebirth," New York, 1976. [Tolstoy, Dostoevsky]

Brailer, Kathryn Anne. "Absurdist Features in Russian Drama: Nineteenth and Twentieth Centuries," Illinois, 1976.

Burago, Alla. "Leskov's Cathedral Folk: A Russian Apocalypse," Texas, 1976.

Carey, Marjorie Ann. "Slavic Roots in Dostoevsky and Conrad: A Study in Themes and Narrative Conventions," Notre Dame, 1977.

Carr, Barbara Catherine L. "Variations on the Anarchist: Politics Reflected in Fiction," Indiana, 1976. [Turgenev, Dostoevsky, Zola, James, and Conrad]

Carr, Nonna Hordowsky. "S. T. Aksakov in Russian Literary Criticism Before 1917," Colorado, 1976.

Colton, Milo L. "The Political Thought of Alexander Solzhenitsyn," Colorado, 1976.

Connolly, Julian Welch. "The Poetry of Ivan Bunin," Harvard, 1977.

Cooney, Terry Arnold. "High Ideals and Political Realities: Literary Radicalism at Partisan Review, 1934-1937," SUNY, Stony Brook, 1976.

Cukierman, Walenty. "The Odessa School of Writers, 1918-1923," Michigan, 1976.

Cunningham, Marina. "Isaac Babel: The Identity Conflict," Northwestern, 1976.

Cvetanović, Nikola Miodrag. "Description in the Prose Works of Ivan Alekseevič Bunin," Ohio State, 1976.

Czyzewski, Frank Joseph. "The Aesthetics of Apollon Grigor'ev: Theory and Practice," Wisconsin, 1976.

Deck, Priscilla Conwell. "Thematic Conference in Bulgakov's The Master and Margarita," Brandeis, 1977.

Dienes, Laszlo. "Russian Literature in Exile: The Life and Work of Gajto Gazdanov," Harvard, 1977.

Ferguson, Dolly Mary. "Lyricism in the Early Creative Prose of Mykola Khvyl'ovy," Toronto, 1977.

Goscilo, Helena Irena. "From Dissolution to Synthesis: The Use of Genre in Lermontov's Prose," Indiana, 1976.

Gregory, Serge Vladimir. "The Literary Milieu of Dostoevsky's The Possessed," Washington, Seattle, 1977.

Gutry, Shirley Ann. "An Approach to The
Master and Margarita Through the Creative Prose and the Letters of M. A. Bulgakov," Princeton, 1976.

Hannaway, Daniel George Michael. "The Life and Works of M. M. Prishvin," Syracuse, 1975.

Hinkle-Kreuzer, Ruth Leslie. "An Analysis of Themes, Characters, and Literary Devices in Vera Panova's Major Fiction," Ottawa, 1977.

Holly, Carol Thayer. "Portraits of the Self in Henry James' Autobiography and Vladimir Nabokov's Speak Memory," Brown, 1976.

Horick, Robert Allan. "Pečorin Redivivus and Salvation Through Art: A Study of the 'Povesti,' Criticism, and Miscellaneous Writings of Aleksandr Vasil'evič Družinin," Chicago, 1974.

Indictor, Rina M. "Fictionalization: The Poetics of Literary Self-Consciousness," New York, 1976. [Dostoevsky]

Isenberg, Charles Richard. "The Literary Prose of Osip Mandel'štam," Harvard, 1977.

Johnson, Phyllis Marie. "Struggle with Death: The Theme of Death in the Major Prose Works of Iu. Olesha and V. Kataev," Cornell, 1976.

Kara-Sokol, Alexander. "Periodical Russkoe Obozrenie," [Russian Text], Vanderbilt, 1976.

Karp, Carole Sue. "George Sand's Reception in Russia, 1832-1881," Michigan, 1976.

Kelley, Geraldine. "The Characterization of Tat'jana in Puškin's Evgenij Onegin," Wisconsin, 1976.

Kisseleff, Natalia. "A Study of the Romantic Hero in Six Nineteenth Century Russian Novels," Toronto, 1976.

Kriskijans, Irene. "On the Structure and Thematics of Dostoevsky's The Devils," Georgetown, 1976.

Kusubova, Tatiana. "Konstantin Korovin as a Writer," California, Berkeley, 1975.

Langen, William George. "The Evolution of French Socialist Realism," Arizona, 1976. [Soviet Literary Theory]

Lanly, Kenneth Alfred. "Aspects of Chekhov's Comedy: 1880-1887," Toronto, 1974.

Larionoff, Nina Adler. "The First Circle' of Aleksandr Solženicyn: Analysis and Interpretation," California, Berkeley, 1975.

Lawton, Anna Maltese. "Main Lines of Convergence Between Russian and Italian Futurism: V. Seršenevič and F. T. Marinetti," California, Los Angeles, 1976.

Leiter, Sharon Libby Sherman. "The City Versions of Osip Mandel'štam," Michigan, 1976.

Lilly, Ian Kenneth. "The Lyric Poetry of N. M. Jazykov; a Periodization Using Objective Criteria," Washington, Seattle, 1977. 
Majhanovich, Ljubo Dragoljub. "The Early Prose of Vladimir Nabokov-Sirin: A Commentary on Themes, Style, and Structure," Illinois, 1976.

Medwidsky, Bohdan. "The Language of Stefanyk's Novellas: An Analysis of the Vocabulary," Toronto, 1977.

Miller, Frank Joseph. "The Folklore of the Stalin Era in the Soviet Union," Indiana, 1976.

Miller, Robin Feuer. "The Multi-Voiced Narrator of The Idiot: An Approach to Understanding the Narrative Methods in Dostoevsky's Novels," Columbia, 1977.

Miller, Tamara Niwnia. "Novyi Mir in 19251934: A Stüdy in Early Soviet Literature and Journalism," Vanderbilt, 1976.

Mitchell, Paul MacArthur, Jr. "Lev Nikolaevich Tolstoy in Pre-Soviet Russian Literary Criticism," Indiana, 1977.

Narwani, Ulrike Ellen. "The Early Prose of A. Remizov, a 'Short Story' Symbolist," Toronto, 1977.

Nassar, Joseph M. "The Russian in Nabokov's English Novels," SUNY, Binghamton, 1977.

Olcott, Anthony Charles E. C. "Andrej Platonov: The Citizen-Artist," Stanford, 1976.

Palumbo, Donald Emmanuel. "Faith, Identity, and Perception-Three Existential Crises in Modern Fiction and Their Artistic Reconciliation: A Comparison of the Fiction of Dostoevsky, Joyce, Kafka, and Faulkner from the Perspective of the Works of Sartre and Camus," Michigan, 1976.

Penny, Bernard. "Vsevolod Mikhailovich Garshin: A Study of the Dynamics of Guilt," Georgetown, 1977.

Peterson, Ronald Eugene. "Andrej Belyj's Short Prose," Harvard, 1977.

Phillips, Delbert Darwal. "The Supernatural Tale: An Analysis of Supernatural Elements in Russian Short Fiction of the First Three Decades of the Nineteenth Century," New York, 1977.

Pifer, Ellen Ina. "No Frivolous Firebird: Character, Reality, Morality in Nabokov's Fiction," California, Berkeley, 1976.

Pisani, Assunta Sarnacchiaro. "The Raging Impotence: Humor in the Novels of Dostoevsky, Faulkner and Beckett," Brown, 1976.

Price, Christiane Bosse. "A Typological Study of Faust: An Analysis of the Thematic Structure in Selected Twentieth Century Faust Drama: German, English, French, American, and Russian Versions," Emory, 1976.

Rabinowitz, Stanley Jay. "Fedor Sologub's Literary Children: From Symbol to Myth," Harvard, 1975.

Reifield, Beatrice Ann. "A Theory of Tragi- comedy in Modern Drama," Pennsylvania State, 1976. [Chekhov]

Rosengrant, Sandra Gayle Freels. "The Theoretical Criticism of Iu. N. Tynjanov," Stanford, 1976.

Rundżjo, Kleofas Hubert. "Surrealizm Rosyjski," Brown, 1976.

Rusinko, Nancy Elaine. "Gumilev's Acmeism: Theory and Practice," Brown, 1976.

Rydel, Christine A. "A Formal Analysis of the Poems of Fedor Ivanovic Tjutčev," Indiana, 1976.

Schefski, Harold Klassel. "Boris M. Eikhenbaum: The Evaluation of His Critical Method and His Contribution to Russian Literary Criticism," Stanford, 1976.

Sokol, Elena. "Crocodiles and Commissars: Early Soviet Poetry for Children," California, Berkeley, 1974.

Spitz, Sheryl Allison. "The Genre of the Lullaby in Russian Folklore and Literatưre," Stanford, 1977.

Steiner, Peter. "From Formalism to Structuralism: A Comparative Study of Russian Formalism and Prague Structuralism," Yale, 1976.

True, Warren Roberts. "Chekhovian Dramaturgy in the Plays of Tennessee Williams, Harold Pinter, and Ed Bullins," Tennessee, 1976.

Vitins, Ieva, "Escape from Earth: A Study of the Four Elements and Their Associations in Marina Cvetaeva's Work," California, Berkeley, 1974.

Vorobiov, Alex. "Pasternak's Lyrical Creativity: The Formative Years, 1912-1922," Illinois, 1976.

Wangler, Lila Hilda. "The Moral and Religious Themes in the Works of Vladimir Tendriakov," Pittsburgh, 1977.

\section{MUSIC}

Baca, Richard. "A Style Analysis of The Thirteen Preludes of Sergei Rachmaninoff," Peabody Institute of the City of Baltimore, 1975.

Bailey, Donald Lee. "A Study of Stylistic and Compositional Elements of Anthem (Stravinsky), Fragments of Archilocos (Foss) and Creation Prologue (Ussachevsky)," Northern Colorado, 1976.

Klimash, Victor A. "The Opera, 'Boris Godunov' of Modest Mussorgsky," Florida State, 1975.

Koskoff, Ellen Gilbert. "The Concept of Nigun among Lubavitcher Hasidim in the United States," Pittsburgh, 1976.

Maloff, Nicholas. "Pushkin's Dramas in Russian Music," Pittsburgh, 1976.

Meeks, John Samuel. "Aspects of Stylistic Evaluation in Scriabin's Piano Preludes," Peabody Conservatory of Music, 1975.

Russell, Walter Saunders, Jr. "Stravinsky 
and Eliot: Personality, Poetics, and Cultural Politics," Emory, 1976.

Smith, Arthur Duane. "Recurring Motives and Themes as a Means to Unity in Selected String Quartets of Dmitri Shostakovich," Oklahoma, 1976.

Tull, James Robert. "B. V. Asaf'ev's Musical Form as a Process: Translation and Commentary," Ohio State, 1977.

\section{PHILOSOPHY AND RELIGION}

Graves, Thomas Henry. "The Relevance of the Personalistic Thought of Nicolas Berdyaev for the Christian-Marxist Dialogue," Southern Baptist Theological Seminary, 1976.

Green, Arthur. "Rabbi Nahman of Bratslav: A Critical Biography," Brandeis, 1975.

Luckens, Michael Jonathan. "Rabbi Levi Yitzhak of Berdichev," Temple, 1974.

Pittman, David Chester. "The Character of Human Freedom and Its Implications for the Parish Minister: An Exploration Based on the Thought of Nicolai Alexandrovitch Berdyaev and Frederick S. Perls," School of Theology at Claremont, 1975.
Steeves, Paul D. "The Russian Baptist Union, 1917-1935: Evangelical Awakening in Russia," Kansas, 1976.

Zakydalsky, Taras Danylo. "N. F. Fyodorov's Philosophy of Physical Resurrection," Bryn Mawr, 1976.

\section{SOCIOLOGY}

Fisher, Wesley Andrew. "The Soviet Marriage Market: Marriage Patterns in the U.S.S.R. Since World War II," Columbia, 1976.

Markus, Daria. "Education of Ethnic Leadership: A Case Study of the Ukrainian Ethnic Group in the United States (1970. 1974)," Loyola, Chicago, 1977.

Milstead, Marlene Stefanow. "Generational Retention of Selected Cultural and Social Characteristics Among Ukrainian-Americans," Louisiana State, 1976.

Smithson, Michael James. "Of Icons and Motorcycles: A Sociological Study of Acculturation among Russian Old Believers in Central Oregon and Alaska," Oregon, 1976.

Von Frank, April Ann Jones. "Family Policy in the USSR Since 1944," Missouri, 1975.

\section{Eastern Europe}

\section{GENERAL}

Barendse, Michael A. "Slavic Immigrants in the Pennsylvania Anthracite Fields, 1880 1902: A Study of the Contrast Between Social Expectations and Immigrant $\mathrm{Be}$ havior," Ball State, 1976.

Benkin, Richard Lee. "Social and Cultural Development of Jewish Life in Eastern Europe and Specification of American Jewishness," Pennsylvania, 1976.

Brookstone, Jeffrey Martin. "Entrepreneurial Politics: The Role of American Multinational Businessmen in the Conduct of U.S. Foreign Policy: A Case Study of East-West Trade and Investment Policies," George Washington, 1976.

Iovine, Micaela Scott. "The History and the Historiography of the Second South Slavic Influence," Yale, 1977.

Jacobson, David Cortell. "The Recovery of Myth: A Study of Rewritten Hasidic Stories in Hebrew and Yiddish, 1890 1910," California, Los Angeles, 1977.

Jones, James Robert. "A Study of the Import Demand for Soybeans and Soybean Products in Eastern Europe," Arkansas, 1976.

Kaiser, David Elmore. "Germany, Britain, France and Eastern Europe, 1930-39: Political and Economic Diplomacy in the Successor States," Harvard, 1976.
Kawalewale, Kammalizeni Julius. "Ostpolitik and West German Public Opinion: An Interpretation," Miami University (Ohio), 1976.

Kirshenblatt-Gimblett, Barbara. "Traditional Storytelling in the Toronto Jewish Community: A Study in Performance and Creativity in an Immigrant Culture," Indiana, 1972.

Koskoff, Ellen Gilbert. "The Concept of Nigun among Lubavitcher Hasidim in the United States," Pittsburgh, 1976.

Lagoe, Ronald John. "Greece and the Great Powers: The Question of the Aegean Islands, 1912-1944," Ohio, 1976.

McGregor, James Paul. "Political Leadership in Eastern Europe in Comparative Communist Perspective," Ohio State, 1975.

Pilzer, Jay Mervyn. "The League of Nations and the Jewish Question," Duke, 1976.

Potter, William Clark. "Continuity and Change in the Foreign Relations of the Warsaw Pact States, 1948-1973: A Study of National Adaptation to Internal and External Demands," Michigan, 1976.

Smith, David Brent. "The Opposition to Ostpolitik Foreign Policy as an Issue in West German Politics, 1969-1972," Harvard. 1976.

Sofer, Eugene Franklin. "From Pale to Pampa: Eastern European Jewish Social 
Mobility in Gran Buenos Aires, 18901945," California, Los Angelés, 1976.

\section{AUSTRIA}

Bogert, Elva Jennette. "Austro-Hungarian Maritime Trade with the Ottoman Empire, 1873-1895: A Commercial History with Diplomatic Considerations," Tufts, 1976.

Forrest, Jacqueline Eileen Darroch. "Fertility Decline in Austria, 1880 to 1910," Princeton, 1976.

Naramore, Ronald Gene. "The Economic History of an Austrian Town," Oklahoma, 1975.

Niesz, John George. "Early Industrialization and the Workers of Lower Austria, 18481873," Rutgers, 1976.

Rebel, Hermann George. "The Rural Subject Population of Upper Austria During the Early Seventeenth Century: Aspects of the Social Stratification System," California, Berkeley, 1976.

Retz, Roberta Till. "Austrian Trade Unions and the 'Woman Question': Socialist and Catholic Approaches, 1890-1914," Oregon, 1976.

Roebke, Ruth Diane. "Austrian Social Democratic Thought on the Nationality Question and Foreign Policy, 1890-1914," Marquette, 1976.

Wagener, Mary Louise. "Pioneer Journalistinnen, Two Early Twentieth Century Viennese Cases: Berta Zuckerkandl and Alice Schalek," Ohio State, 1976.

Webster, Ronald Denys Edwin. "Radical Nationalists of the Reich and the German Problem in the Danube Monarchy, 18961914," Toronto, 1974.

\section{BULGARIA}

Karriker, Robert John. "Beginning Bulgarian: A Programmed Language Course," Stanford, 1976.

Weissman, Eric R. "The Cooperative Movement in the Bulgarian Village Prior to World War One," Washington, Seattle, 1977.

\section{CZECHOSLOVAKIA}

Green, Simon Rosengard. "Thomas Garrigue Masaryk: Educator of a Nation," California, Berkeley, 1976.

King, Arthur Eaton. "An Econometric Model of a Socialist Economy: Czechoslovakia," Ohio State, 1976.

Kovanda, Karel. "Labor in Management, Czechoslovakia 1968-69: A Study in Radical Democracy," Massachusetts Institute of Technology, 1975.

Oncley, Lawrence Alan. "The Published Works of Alexander Zemlinsky," Indiana, 1975. [in Czechoslovakia 1911-1927]
Perina, Rudolf Vilem. "Intellectuals and Political Change in Czechoslovakia: A History of Literárni Noviny and Its Contributors, 1952-1969," Columbia, 1977.

Peterson, James Walter. "Political Leadership in Czechoslovakia 1954-1966," Indiana, 1976.

Rosenfeld, Stella. "Johannes Urzidil's Prague and Bohemian Stories: Major Aspects of Subject Matter and Theme," Case Western Reserve, 1976.

Stevens, John Nelson. "The Political Economy of Czechoslovak Foreign Trade, 1948-1968," Pennsylvania State, 1977.

\section{EAST GERMANY}

Bissett, Judith Ishmael. "ConsciousnessRaising Dramatic Structures in Latin America's Theater of Commitment," Arizona State, 1976. [Brecht]

Brown, Corinne Annette. "Ionesco vs. Brecht: The Tyranny of Non-Commitment," Arkansas, 1976.

Campbell, Johnstone. "American Culture and the Art of Bertolt Brecht: A Succession of Dawns," Stanford, 1976.

Fischer, Gerhard. "The Paris Commune on the Stage: Vallès, Grieg, Brecht, Adamov: A Comparative Study about the Representation of Historical Reality in Modern Theatre," SUNY, Binghamton, 1976.

Hill, Victoria Williams. "Bertolt Brecht and Post-War French Drama," Wisconsin, 1976.

Hoffmann, Stephen Paul. "National Tradition and the Development of the German Democratic Republic: 1945-1971," Princeton, 1976.

Kuplis, Aija. "The Image of Woman in Bertolt Brecht's Poetry," Wisconsin, 1976.

Lellis, George Patrick. "From Formalism to Brecht: The Development of a Political and Aesthetic Sensibility in Cahiers $d u$ Cinema," Texas, 1976.

Liddell, Peter Graham. "Individuality and Collectivism: The Evolving Theory and Practice of Socialist Realism in East Germany Reflected in Three Novels of the 1960's," British Columbia, 1977.

Papero, Daniel Vail. "Johannes Bobrowski's Levins Mühle: A Socio-Literary Analysis," Indiana, 1976.

Rothstein, Paula. "Brechts 'Baal' und Die Moderne Agressions Forschung," New York, 1976.

Scheid, Judith Roberta. "Enfant Terrible of Contemporary East German Drama: Peter Hacks in His Role as an Adaptor and Innovator," Indiana, 1976.

Springfield, Asalean. "Bertolt Brecht's The Caucasian Chalk Circle and Pierre-Joseph Proudhon's Political Philosophy," American, 1976.

Timm, Neil Herman. "A Comparative Study 
of Pirandello, Yeats, and Brecht: The Mask as a Paradigm for Modern Theater," Columbia, 1976.

\section{HUNGARY}

Bell, Louis Michael. "János Arany's Toldi: An Introductory Essay and Introduction," Princeton, 1975.

Bellak, Richard Charles. "Compositional Technique in the Transcriptions of Franz Liszt," Pennsylvania, 1976.

Beyer, William Huntley. "Compositional Principles in Three Works of György Ligeti," Washington, Seattle, 1975.

Drosick, Sandor Desmond. "The Agrarian Socialist Movement in Hungary 18901899," Columbia, 1976.

Ford, Kathleen. "Abortion and Family Building: Fertility Limitation in Hungary and Japan," Brown, 1976.

Gal, Susan. "Language Change and Its Social Determinants in a Bilingual Community," California, Berkeley, 1976.

Gluck, Mary. "Endre Ady: An East European Response to the Cultural Crisis of the fin de siecle," Columbia, 1977.

Kaufmann, Thomas Da Costa. "Variations on the Imperial Theme: Studies in Ceremonial Art, and Collecting in the Age of Maximilian II and Rudolf II," Harvard, 1977.

Szentkirályi, András. "Bartók's Second Sonata for Violin and Piano (1922)," Princeton, 1976.

Zarychta, Ronald Michael. "Louis Kossuth and the United States, 1848-1852," Carnegie-Mellon, 1976.

\section{POLAND}

Antkiewicz, Henry John. "Leon Wasilewski: Polish Patriot and Socialist," Ohio State, 1976.

Armstrong, Daniel Paul. "Beyond Psychoanalysis: A Re-Examination of Conrad's Fiction in the Light of His Polish Heritage," Indiana, 1976.

Atkins, Thomas V. "The Dynamics of a Popular Revolt: A Case Study of Poland, 1956-1957," New School, 1977.

Dembrowski, Harry Edward. "The Union of Lublin: Polish Federalism in the Golden Age," Chicago, 1974.

Harwood, William L. "Ignacy Daszinski: The Making of an Austro-Polish Statesman, 1866-1918," Illinois, 1977.

Kaba, Brahima Diakity. "Effects of Women's Employment on Household Activity and Expectations: The Polish Case," Boston University, 1977.

Kadlubowski, John Felix. "The Experts and Poland's Frontiers at the Paris Peace Conference," Maryland, 1977.
Konczakowski, Edmund Francis. "Vatican Policy Toward the German-Polish OderNeisse Line: A Study of Foreign Policy Evolution, 1945-1972," Pennsylvania, 1976.

Levin, Nehemia. "The Attitudes of Jewish Administrators of Russian, Polish, and Israeli Descent in Institutions of Higher Education in Israel toward Students of Ashkenazic and Sephardic Oriental Backgrounds," Connecticut, 1977.

Miller, Stefania Szlek. "Church/State Relations in Poland, 1956-1970. The 'Znak' Group: 'Priests' or 'Jesters,'” Toronto, 1976.

Pernal, Andrew B. "The Polish Commonwealth and Ukraine: Diplomatic Relations 1648-1659," Ottawa, 1977.

Sysyn, Frank. "Adam Kysil, Statesman of Poland-Lithuania: A Study of the Commonwealth's Rule of the Ukraine from 1600 to 1653 ," Harvard, 1976.

Thackeray, Frank William. "Alexander I and the Polish Congress Kingdom: A Study in Russo-Polish Political Relations, 1815-1825," Temple, 1977.

Zatlokal, Barbara Margaret. "The Foreign Image of Mickiewicz in Nineteenth and Twentieth Century Criticism and Public Opinion in Europe and America," Indiana, 1976.

\section{RUMANIA}

Chaplin, Arie. "Security of Weak States: The 'Popular War' Doctrine in Romanian Defense Policy," New School, 1977.

Dieteman, Charles James. "Austria-Hungary and the Development of Romanian Independence, 1878-1883," Washington, Seattle, 1977.

Gamzu, Joseph. "Poetic and Linguistic Symbiotic Phenomena in Itzik Manger's Biblical Poetry," Texas, 1976.

Linden, Ronald Haly. "Normative Integration in an International Region: East Europe and Romania, 1965-1969," Princeton, 1976.

Verdery, Katherine Maureen. "Ethnic Stratification in the European Periphery: The Historical Sociology of a Transylvanian Village," Stanford, 1977. [RumanianHungarian]

\section{YUGOSLAVIA}

Bennett, Linda Anne. "Patterns of Ethnic Identity among Serbs, Croats, and Slovenes in Washington, D.C.," American, 1976.

Campbell, Faith Thompson. "The Press and the Self-Management Movement in Yugoslavia (1968-1971)," Princeton, 1975.

Curčić, Slobodan. "Gračanica: History, Architecture and Relationship to Contem- 
porary Palaeologan Churches" New York, 1975.

Donia, Robert Jay. "The Politics of Factionalism: The Bosnian Moslems in Transition, 1878-1906," Michigan, 1976.

Eichel, Marijean Hamilton. "Dalmatia in Microcosm: An Historical Geography of Changing Land Use in Brač, Yugoslavia," California, Berkeley, 1975.

Flores, Luis Gilberto. "Organization Goals, Growth and Growth Strategy in the Peruvian Co-Determination and the Yugoslav Self-Determination Systems," Texas Tech, 1976.

Johnson, Vidosava Taranovski. "Ivo Andrić: The Development of the Bosnian Story," Harvard, 1977.

Jovkovic, Ljiljana. "Syntactic Development of Yugoslav Students of English," Florida State, 1976.

Jurisich, Dragoslav. "The Case System in Standard Serbo-Croatian," Simon Fraser. 1977.

Lazarevic, Milo. "Yugoslav Contemporary Sculpture," Columbia, 1977.
Pavichevich, Helen A. "Education and Modernization in Montenegro, 1831-1918," Loyola, Chicago, 1976.

Petrovich, Miodrag B. "A Mediterranean City-State: A Study of Dubrovnik Elites, 1592-1667," Chicago, 1974.

Scoles, Regina Curtis. "Teodosije Hilandarac: An Investigation into Early Serbian Literature," Ohio State, 1976.

Seroka, James Henry. "Local Public Policies and Public Policy Decision-Making in Yugoslavia: An Empirical Analysis," Michigan State, 1976.

Sletzinger, Martin Charles. "The Reform and Reorganization of the League of Communists of Yugoslavia, 1966-1973," Harvard, 1977.

Stermole, David Francis. "Dialectology of a System of Carinthian Slovenian Adverbs," Toronto, 1977.

Tsai, Hui-Liang. "Demand for and Supply of Money: A Comparative Analysis of Canada, Taiwan, Yugoslavia and the United States," Florida State, 1976. 


\section{BRITISH DISSERTATIONS}

\section{Russia and the Soviet Union}

Beaumont, Joan E. (née Magor). "Great Britain and the Soviet Union: The Supply of Munitions, 1941-5," London, 1975.

Cann, Joan. "Britain and the Anglo-French Negotiations with Russia (March-August 1939): With an Analysis of the DecisionMaking Process," Keele, 1975.

Clendenning, Philip Hamlin. "The AngloRussian Trade Treaty of 1766," Cambridge, 1976.

Collins, D. N. "The Origins, Structure and Role of the Russian Red Guard," Leeds, 1975.

Hughes, Lindsey Audrey Jennifer. "Moscow Baroque Architecture: A Study of One Aspect of Westernisation in Late Seventeenth Century Russia," Cambridge, 1977.

Karawalla, G. J. "A Comparative Study of Factors Influencing the Language Policies in India and the USSR," London, 1975.

Kilby, D. A. "Deep and Superficial Cases in Russian," Edinburgh, 1975.

Offord, D. C. "Revolutionary Populist
Groups in Russia in the 1880's," London, 1975.

Pearse, D. J. "French and British Opinion Concerning Russia, 1815-25," Liverpool, 1975.

Sella, A. "Surprise Attack: Soviet Response to German Threats, December 1940-June 1941," Edinburgh, 1975.

Sklar, S. "The Relationship Between Social Context and Individual Character in the Naturalist Drama, with Special Reference to Chekhov, D. H. Lawrence and David Storey," London, 1975.

Strachan, Hew Francis Anthony. "The PreCrimean Origins of Reform in the British Army," Cambridge, 1977.

Waight, Terence. "The Pronunciation of Words of Foreign Origin in Standard Modern Russian," London, 1977.

Zurowski, M. A. "British Policy Towards the Polish-Soviet Border Dispute, 193945," London, 1975.

\section{Eastern Europe}

Brown, Mark Liam. "The Polish Question and Public Opinion in France 1830-1846," Cambridge, 1977.

Coutouvidis, J. "The Formation of the Polish Government in Exile and Its Relations with Great Britain, 1939-41," Keele, 1975.

Deletant, Dennis J. "A Textual Study of the Ieud Manuscript," London, 1976.

Dennell, Robin William. "Neolithic and Bronze Age Economies in Bulgaria," Cambridge, 1977.

Moss, Linda Mary. "The Art of Preslav: Its Sources of Inspiration and Influence," Cambridge, 1977.

Scott, J. V. "Revolutionary Marxism and the Ideological Odyssey of André Malraux and Milovan Djilas," Strathclyde, 1975.
Seliktar, O. "The German Problem in Gomulka's Foreign Policy, 1942-49: A Case Study in Multi-Dimensional Interaction in Foreign Policy Formulation," Strathclyde, 1975.

Theobold, J. R. P. "The Response of the Jewish Intelligentsia in Vienna to the Rise of Anti-Semitism, with Special Reference to Karl Kraus," Southampton, 1975.

Wistrich, R. S. "Socialism and the Jewish Question in Germany and Austria (1880 1914)," London, 1975.

Yarwood, D. "The Vocabulary of Knowledge and Understanding in Serbo-Croat and English," Edinburgh, 1975. 